\title{
OPPORTUNISTIC ADAPTATIONS TO MAN-INDUCED HABITAT CHANGES BY SOME SOUTH AMERICAN CAPRIMULGIDAE
}

\author{
INGELS, J., ${ }^{1}$ ONIKI, Y. ${ }^{2}$ and WILLIS, E. O. ${ }^{2}$ \\ ${ }^{1}$ Galgenberglaan 9, B-9070 Destelbergen, Belgium \\ 2Departamento de Zoologia, Universidade Estadual Paulista "Julio de Mesquita Filho", UNESP, C.P. 199, \\ CEP 13506-900, Rio Claro, SP, Brazil \\ Correspondence to: Johan Ingels, Galgenberglaan 9, B-9070 Destelbergen, Belgium, \\ e-mail: johan.ingels@bira-iasb.oma.be \\ Received August 14, 1998 - Accepted November 18, 1998 - Distributed December 22, 1999
}

\begin{abstract}
We describe the opportunistic adaptation to man-induced changes in the habitats of six neotropical Caprimulgidae. Habitats created by those changes, and similar to their original and usual ones, are readily occupied by these nightjars. The occasional invasion of urban environments ("urbanization") is the most recent and most remarkable behavioural adaptation.
\end{abstract}

Key words: habitats, urbanization, neotropical, Caprimulgidae.

\section{RESUMO}

\section{Adaptações às mudanças de hábitat pelo homem em alguns} Caprimulgidae da América do Sul

Descrevemos a adaptação oportunista de seis caprimulgídeos neotropicais aos hábitats induzidos pelo homem. Os ambientes criados por essas mudanças e semelhantes aos orginais são prontamente ocupados por esses caprimulgídeos. A invasão de ambientes urbanos ("urbanizados") é a mais recente e mais extraordinária adaptação comportamental.

Palavras-chave: ambientes, urbanização, neotropical, Caprimulgidae.

\section{INTRODUCTION}

Caprimulgidae in general are active at night and roost by day. Moreover, most species breed on the ground, and thus their eggs and young are vulnerable to disturbance by humans and predation by ground predators such as dogs and cats. For these reasons, nightjars are mostly found in biotopes where little or no human activities interfere with their characteristic way of living.

Nowadays however, many towns in South America have grown into metropolises, and large parts of the remote interior have been opened up. Although the life histories of caprimulgids are not really compatible with human presence, these developments have influenced the habits of some species, causing an opportunistic adaptation to these changes. Obviously this adaptation is or has been a slow process, best discerned in common and widespread nightjars, which are now found in man-altered environments also.

Clearly, the name "caprimulgid" came from the genus name of Caprimulgus europaeus, for the well-known European Nightjar, sometimes found chasing insects in corrals, but imagined to suck goats at night (Latin: capri $=$ goat and mulgus $=$ milking), indicating an early adaptive behaviour of this species in prehistoric Europe.

This was the origin of the legend of "goatsucker" or "chupa-cabras", a strange animal that attacked domestic ones, recently revived in Brazilian newspapers and television. 
We describe here opportunistic adaptations to man-induced habitat changes in the following species: Nacunda Nighthawk Podager nacunda, Pauraque Nyctidromus albicollis, Band-winged Nightjar Caprimulgus longirostris, Blackish Nightjar C. nigrescens, Scissor-tailed Nightjar Hydropsalis torquata and Sickle-winged Nightjar Eleothreptus anomalus.

\section{METHODS}

The authors have some or extensive field experience with the six mentioned nightjars, in several South American countries: Brazil, Ecuador, French Guiana, Suriname and Venezuela (Ingels \& Ribot, 1983; Oniki \& Willis, 1982, 1983). Our observations were done during field work with caprimulgids in particular or during other avifaunal studies, with use of binoculars Nikon 9 x 23, Zeiss $8 \times 30$ and Asahi Pentax 7 x 35.

We consulted older field guides (Penard \& Penard, 1910; Chubb, 1921; Chapman, 1917) to learn about the earlier distribution and habitats preferred by the nightjars discussed here.

\section{RESULTS}

\section{Nacunda Nighthawk Podager nacunda}

Originally, the Nacunda Nighthawk occupied open grassland, principally where fire or recent floods had kept the grass short. It often roosts near a pile of dung, perhaps a hangover from days when it followed the extinct Pleistocene megafauna (Yamashita \& Cintra, 1994).

It has already been observed to forage under urban illumination in cities and under airport lights in Brazil (Sick, 1993).

In São Paulo localities, Oniki and Willis have noted it flying over city roofs (e.g. in Marília), or have encountered it at the edges of lawns in large university grounds (Araraquara), in polo grounds (Morro Agudo) and in recently cutover sugar cane fields (Pontal), all open habitats similar to natural ones.

\section{Pauraque Nyctidromus albicollis}

Originally, the Pauraque inhabited all sorts of semiopen country, from semiarid regions with light vegetation to swampy areas and natural openings in rainforest. Its optimum habitat contained woodland edges, thickets or other low, dense vegetation where it could rest undisturbed by day, alternating with open spaces where it could sally from the ground at night.

Nowadays, the Pauraque is observed more and more in environments where human intervention created suitable possibilities similar to the above described habitats. In Brazil (São Paulo area) and in French Guiana (near Kourou) (Ingels, 1975), we found it roosting by day in tree plantations and other cultivated areas, man-made clearings in rainforest and second growth forest, along quiet roads and railroads, even around lone dwellings and in villages. It does not persist where cats and dogs are common, however (Oniki \& Willis, pers. $o b s$.).

\section{Band-winged Nightjar Caprimulgus longirostris}

The Band-winged Nightjar has always been widespread throughout South America, from northern Venezuela to Chile and Argentina.

Originally, it inhabited grassy areas, open slopes and woodland borders in highlands up to 3,300 $\mathrm{m}$, even above the treeline, in páramo. In Itararé (São Paulo), Oniki and Willis found it in rocky areas roosting under nearby shrubs for midday shade.

Nowadays, it has extended its range into lower elevations in southeastern Brazil and the coastal region of Peru and Chile (Belton, 1984; Sick, 1993).

Recently however, the Band-winged Nightjar has invaded such large cities as Rio de Janeiro and Santo Amaro, where it is now found in certain neighbourhoods and is often heard calling at night. Therefore its local name in Brazil is "bacurau-detelha" (rooftile nightjar). The opportunistic behaviour of this nightjar results in such remarkable adaptations as feeding on insects attracted by street lights, resting on illuminated closed windowsills, or roosting on walls and roofs, even nesting on flat roofs (Sick, 1993).

Willis has seen it also along roads in Puracé (Colombia) and the Chapada dos Veadeiros (Brazil) where it lives in rocky upland zones normally.

\section{Blackish Nightjar Caprimulgus nigrescens}

Originally, the Blackish Nightjar inhabited sandy and stony areas, large granite outcrops in savannas and rainforests, and stony and rocky sandbars in and along rivers. There it roosts near scattered high weeds or low bushes by day, and 
forages over the open savanna, granite outcrop or river at night.

Nowadays, the Blackish Nightjar also occurs among weeds beside quiet roads in the interior of Amazonian South America, and in clearings or pits where laterite or gravel was dug to repair these roads (called "piçarreiras" in Brazil). Here, it roosts near weeds or bushes by day and forages over the road and laterite or gravel pit at night. It also breeds in these man-created habitats (Ingels, 1981; Oniki \& Willis, 1983; Roth, 1985).

This nightjar is often found in large numbers in such sites. Along roads in southwestern Suriname, recently opened up for the Avanavero barrage project, Ingels estimated a density of approximately 6 pairs per $\mathrm{km}$ of roadside. In larger gravel pits with scattered low weeds and bushes, he observed up to 5 pairs per ha.

\section{Scissor-tailed Nightjar Hydropsalis torquata}

The Scissor-tailed Nightjar lives at edges of savanna or rocky places where it flies low or waits to sally from open sites (Sick, 1993). Moonlight along trails oriented east and west helps males display, alternating at a place on the ground and one on a low limb, several meters off the ground (Willis, pers. obs.)

It now often occurs on roads in semiopen zones, especially at borders or even into sugar cane fields, for instance at Rio Claro (São Paulo, Brazil), as scattered birds or even in small groups.

\section{Sickle-winged Nightjar Eleothreptus anomalus}

The Sickle-winged Nightjar is said to live in marshy grassland, thus its Brazilian name "curiango-do-banhado" (Sick, 1993). But on 11 September, 1997, Willis and students found a male running like a little rat at a road edge in highaltitude dry grasslands of the Serra da Canastra, Minas Gerais $\left(20^{\circ} 12^{\prime} \mathrm{S}, 46^{\circ} 36^{\prime} \mathrm{W}\right)$, then stopping to watch for flying insects. With flashlight and cap, students captured and photographed this male. Others were observed on roads in November, 1998, by Willis and H. Remold.

Oniki, Willis and Marcelo Vasconcelos found scattered birds of this species (or C. longirostris, but lack of white on the short tail, and a pale area over the eye, suggested E. anomalus), waiting or scurrying on the paved road in open areas high on the dry Serra da Piedade, Minas Gerais (1,500 m, 1949' S, 4340'W) on 22 December, 1997.

\section{DISCUSSION}

It is well known that Common Nighthawks Chordeiles minor regularly use flat, gravel roofs for roosting and nesting, in villages and towns throughout their range in North America (Brigham, 1989; Walbeck, 1989). In Brazil in winter, lone birds or groups can roost by day along limbs of scattered trees in city parks, campuses, ranch headquarters and similar sites (Willis et al., pers. obs.).

More recently, a similar "urbanization" has also been observed in the Franklin's or Savanna Nightjar Caprimulgus affinis in several towns in Indonesia, as in Jakarta (Harvey, 1976). The same phenomenon has been seen in the Freckled Nightjar C.tristigma in such towns as Pretoria and Durban in South Africa (Clancey, 1972) and in the Madagascar Nightjar C. madagascariensis for Tananarive in Madagascar (Benson et al., 1976).

In some recent instances of urbanization, the caprimulgids seem to live all year round in their built-up habitat. If flat roofs are not used as breeding sites, then either they nest on the few open or waste grounds in town, or they nest outside the city and come into the urban environment to feed at night. The latter possibility seems unlikely, as this daily movement would presumably be noticed.

Caprimulgids are usually heard or seen after sunset when calling or flying around street lights and lighted buildings. It is obvious that they are attracted to lights or lighted constructions where they prey on insects attracted to such places.

An obvious advantage of the "flat roof habitat" in urban areas is that little human disturbance occurs. This habitat is thus a partial, artificial replacement for the natural habitat. However, roofs are hot during midday hours, possibly restricting nesting and roosting activities; if so, populations could not increase much. Common Nighthawks were observed to prefer roof areas shaded by walls or chimneys where available, to roost and to incubate eggs and the semi-precocial young move to shaded areas during hot middays (Walsberg, in litt.).

The invasion by nightjars of environments altered by human activities, e.g. agricultural, mining and other activites, entails often a slight modification of their life history. The Pauraque for example, has always easily occupied clearings, light second growth forests, etc. that resulted from 
such activities. However, this use of new habitats is more pronounced and obvious when larger areas are opened up by road construction. The Blackish Nightjar e.g. invades very quickly sides of roads, and gravel or laterite pits, both stony areas, along newly opened roads. The newly occupied habitats resemble the original, more natural ones.

Nightjars generally avoid unbroken forests, scrub or grassland, living at edge sites where there is room and sufficient light at night to sally upward from open ground or fly about for hunting prey. A few species, as the Ocellated Nightjar Nyctiphrynus ocellatus, nest on the forest floor, singing and foraging high in the canopy - which is, in a sense, an "edge". Human-made clearings initially provide new habitats for several of these edge-living "nocturnal flycatchers", as for species of Tyrannidae and Muscicapidae. For a very few species, city roofs can replace natural rocky openings ( $C$. longirostris) or burned areas (Chordeiles minor).

However, even species that initially become common in human used environments, and along roads and borders, tend to disappear with more intensive cultivation and human traffic. We have found many killed by cars, and nightjars only persist where roads are used very little. Wires, antennas and other aerial obstructions kill or maim birds around buildings or roads (Bornschein et al., 1996). Intensive agriculture removes patches of woods or bushes where they nest or hide during the day. Cats, dogs, rats and people kill or disturb birds and destroy nests. As a result, one sees few nightjars in cities, suburbs, or heavily used areas, more in peripheral zones, and few again in unbroken forests (where owls and potoos take their place). Expansion is thus temporary, ending with increasing human density.

Acknowledgments - We thank Miss P. Santana (Brazil) for slides of Rio de Janeiro's "roof habitat", H. D. Jackson (New Zealand) for copies of relevant literature on African caprimulgids, and M. W. Weller and R. M. Brigham (USA) for slides of Common Nighthawks on flat roofs and in natural habitats. Oniki and Willis are grateful for a grant from the Volkswagen Stiftung (Germany) for work in Minas Gerais.
BENSON, C. W., COLEBROOK-ROBJENT, J. F. \& WILLIAMS, J. F., 1976, Contribution à l'ornithologie de Madagascar. L'Oiseau et R.F.O., 46: 209-242.

BORNSCHEIN, M. R., REINERT, B. L., \& BOCON, R., 1996, A new record of the Sickle-winged Nightjar Eleothreptus anomalus for southern Brazil. Bull. B. O. C., 116: 12-125.

BRIGHAM, R. M., 1989, Roost and nest sites of the Common Nighthawk: are gravel roofs important? Condor, 91: 722-724.

CHAPMAN, F. M., 1917, The distribution of bird-life in Colombia: A contribution to a biological survey of South America. Bull. Am. Mus. Nat. Hist., 55: 1-769.

CHUBB, C., 1921, The birds of British Guiana, based on the collection of F. Vavasour McConnell, Camfield Place, Hatfield, Herts. London.

CLANCEY, P. A., 1972, The Freckled Nightjar in a built-up urban area. Ostrich, 43: 63-64.

HARVEY, W. G., 1976, Caprimulgus affinis as an urban species in Indonesia. Bull. B. O. C., 96: 122-123.

INGELS, J., 1975, Notes on the Pauraque Nyctidromus albicollis in French Guina. Bull. B. O. C., 95: 115-116.

INGELS, J., 1981, Notes on some Suriname birds. Bull. B. O. C., 101: 363-370.

INGELS, J. \& RIBOT, J. -H., 1983, The Blackish Nightjar (Caprimulgus nigrescens) in Surinam. Gerfaut, 73: 127146.

ONIKI, Y. \& WILLIS, E. O., 1982, Breeding records of birds from Manaus, Brazil: I. Accipitridae to Caprimulgidae. Rev. Brasil. Biol., 42: 733-740.

ONIKI, Y. \& WILLIS, E. O., 1983, A study of breeding birds of the Belém area, Brazil: II. Psittacidae to Trochilidae. Ciência e Cultura, 35: 956-964.

PENARD, F. P. \& PENARD, A. P., 1910, De vogels van Guyana (Suriname, Cayenne en Demerara). 2 vols. Paramaribo.

ROTH, P., 1985, Breeding biology of the Blackish Nightjar, Caprimulgus nigrescens, in western Brazil. Gerfaut, 75: 253-264.

SICK, H., 1993, Birds in Brazil. A Natural History. Princeton (USA).

WALBECK, D. E., 1989, Observations of roof-nesting Killdeer and Common Nighthawks in Frostburg, Maryland. Maryland Birdlife, 45: 39.

YAMASHITA, C. \& CINTRA, R., 1994, O mimetismo do curiango (Podager nacunda), Caprimulgiformes, e a ocupação dos sítios degradados por herbívoros de grande porte. Resumos Congr. Brasil. Ornit., 4: 140.

\section{REFERENCES}

BELTON, W., 1984, Birds of Rio Grande do Sul, Brazil. Part 1. Rheidae through Furnaridae. Bull. Am. Mus. Nat. Hist., 178(4): 369-636. 